\title{
DESCRIBING NON-INDUSTRIAL PRIVATE FOREST OWNERSHIP IN ESTONIA: A QUALITATIVE APPROACH
}

\section{Priit Põllumäe, Kristjan Sepp}

Estonian University of Life Sciences

priit.pollumae@emu.ee

\begin{abstract}
Private forestry and forest owners in Estonia have become more profound research subjects in the last decade. One of the most common research topics has been the identification of private forest owners' (PFO) values and objectives. However, much of the existing studies rely on quantitative data which usually describes more active owners and owners whose forest property is larger than the average. Thus, the aim of the present study is to identify the management objectives and motives of non-industrial private forest owners using a qualitative approach - something that has been rarely used in forest owners' research in Estonia. Eight forest owner interviews form the dataset, which is analysed in order to identify PFO forestry objectives and forest use. The results of our qualitative content analysis show, in principle, similar generalized forest owner types of motivations. However, the qualitative approach opens up these generalized types even more. Income motive goes beyond just continuous financial returns and means in many cases a sense of security. Forest ownership is closely linked with "home" interpretations. We conclude that qualitative methods in small-scale forestry research provide new insights to forest ownership and its meanings to private forest owners.
\end{abstract}

Key words: private forest, interview, small-scale forestry, forest management, NIPF owner, motives.

\section{Introduction}

Changes in forest ownership is a normal phenomenon. However, many Central and Eastern European (CEE) countries have experienced changes rapidly and first hand due to the collapse of the Soviet Union. In Estonia, private forest ownership was reestablished with the land and ownership reform initiated in 1993 (Meikar \& Etverk, 2000). The process has led to a restructured forest ownership where, according to the National Forest Inventory (NFI) data the state owns $44 \%$ and private owners $48 \%$ of the total $(2.2$ million hectares i.e. $50 \%$ of land cover) forest land (Keskkonnaagentuur, 2016). It is expected that the share of private forest increases even more as about 177000 hectares $(8 \%)$ of forest is still subject to privatization (Keskkonnaagentuur, 2016). With this change, also the number of forest owners has increased. In 1994, it was estimated that there are 10,200 private farms that own forest
(Leemet \& Karoles, 1995), in 2011, the number of private forest holdings reached 52,000 (Toivonen et al., 2005). However, in most cases the estimates on PFO structure have mostly been approximate expert opinions. Only quite recently, in 2011, the Ministry of Environment (2011) initiated a study on private ownership structure and forest use. The results indicate that most of the forest owners are private individuals. Such forest owners are often referred to as non-industrial private forest owners (NIPF), mostly in the US (e.g. Bliss \& Martin, 1989; Zhang, Zhang, \& Schelhas, 2005). Recent trends in Estonia show that the number of NIPF owners is increasing while their share of forest ownership is decreasing (table 1). This indicates that the degree of ownership fragmentation is significant and poses questions why these processes are taking place and how this influences the future management of these forests.

Table 1

General trends of private forest ownership

\begin{tabular}{|l|c|c|}
\hline \multicolumn{1}{|c|}{ Indicator } & $2015^{1}$ & $2010^{2}$ \\
\hline Number of private individual forest owners (from total, \%) & $107,170(95 \%)$ & $93,271(96 \%)$ \\
\hline Number of legal (companies, trusts etc.) forest owners (from total, \%) & $5752(5 \%)$ & $4001(4 \%)$ \\
\hline $\begin{array}{l}\text { Forest land in private individual forest ownership, ha (from total private } \\
\text { forest, \%) }\end{array}$ & $688,246(65 \%)$ & $747,827(74 \%)$ \\
\hline Forest land in legal forest ownership, ha (from total private forest, \%) & $377,747(35 \%)$ & $262,960(26 \%)$ \\
\hline Average forest area for private individual forest owners, ha & 6.4 & 8.0 \\
\hline Average forest area for legal forest owners (companies), ha & 65.7 & 65.7 \\
\hline
\end{tabular}

${ }^{1}$ Ministry of Environment 2015

${ }^{2}$ Ministry of Environment 2011 
Private forestry and forest owners in Estonia have become more profound research subjects in the last decade. More recent research in Estonia (e.g. Toivonen et al., 2005; Sepp, 2008; Põllumäe et al., 2014a; Põllumäe, Korjus, \& Paluots, 2014b; Põllumäe, Lilleleht, \& Korjus, 2016) about private forest owners includes questionnaire survey data obtained from owners of larger than the average forest holdings. The data collection has involved samples taken from forest owners' organisation (FOO) networks or support measure databases. There are several reasons for that. One has been the need to have valid survey results (Toivonen et al., 2005) and others link with administrative reasons (e.g. Põllumäe, Korjus, \& Paluots, 2014b). For example using existing FOO enables to gain the data with lower costs and with better response rates. For these reasons, it is difficult to extend many of the previous research findings to the overall forest owner population. Moreover, there is even a larger gap in understanding the management or ownership rationale of small-scale PFO as to date there is very little knowledge about the Estonian NIPF owners. Therefore, the aim of this study is to identify the management objectives and motives of selected NIPF owners using qualitative methods (as suggested by Põllumäe 2015). The choice of the method was driven mainly by the interest to have more detailed information that could go beyond the descriptive characteristics of quantitative data. Fischer et al. (2013) states that qualitative methods reflect better the attitudinal or psychic perceptions of the subjects.

\section{Theoretical background and literature}

Describing forest owners has been often limited to using quantitative solutions (e.g. cluster analysis). Põllumäe (2015) has outlined that PFO classifications are useful for designing more long-term objectives for forest policy due to the high level of generalization of these owner types. However, such broad descriptions might not be appropriate to implement everyday policy tools because the success of the implementation depends on how the design of the tools reflect the target group (Pregernig, 2011). Qualitative methods could be one way to overcome this barrier. Bliss and Martin (1989) used qualitative methods already in the end of 1980es to investigate NIPF management motives in the US. Among other things, they found more explained reasons for NIPF owners to produce timber. Former quantitative and neoclassical approaches had viewed private forest owners has rationale profit maximizers. In mid-1990es, Lönnstedt (1997) used qualitative methods to analyse the goals of ownership and found in case of Sweden that NIPF owners have long-term perspectives towards their ownership. A more recent qualitative forest owner study from Lithuania concludes that the regulation of forest policy does not fit well with the existing forest ownership characteristics (Stanislovaitis et al., 2015). In Estonia, Grubbström (2011) used both qualitative and quantitative methods and investigated the emotional obstacles to land sale in Northwest Estonia. She concluded that there are often strong values attached to the land and that these values are mostly non-monetary in that particular region. Overall, valueand objective-based forest ownership typologies are the rather common subjects in forest policy research (Weber, 2012). Also in Estonia, Sepp (2008) used cluster analysis to segment the owners. He found that four main types - timber producers $(23 \%)$, multipleusers (versatile producers. 10\%), bystanders $(27 \%)$ and indifferent or less active owners (40\%). In 2014, Põllumäe, Korjus, \& Paluots (2014) went a bit further by using principal component analysis to calculate the motives of forest owners. They did not group or segment the owners in specific groups. Instead, they concluded that different motives are present at the same time and situational aspects (policies or life events) initiate or prevent the realization of different motives (conservation motive, non-wood motive, income motive, 'home' motive, self-consumption motive). However, both (Sepp, 2008; Põllumäe, Korjus, \& Paluots, 2014) studies rely on data, which reflects more the attitudes of larger-than-average forest owners. In addition, both studies generalize in a way, which might not reveal the actual diversity in different motives or objectives. Similar pros and cons between qualitative and quantitative approaches in PFO research have also been found for example by Bengston, Asah, \& Butler (2011), Fischer et al. (2013) and Stanislovaitis et al. (2015).

\section{Materials and Methods}

In order to obtain the data and reach the respondents, different strategies of purposeful sampling (with emphasis on similarity) were used (Patton, 2014). Firstly, the interviewees were reached through personal connections or through some key informants (i.e. chair persons of regional forest owners associations). It is therefore that the sample is purposeful in order to provide full information about the targeted subjects as the interviewees were chosen mainly according to their property size (forest area not more than 20 hectares). Our aim was to have a small-scale forest owner's perspective (criterion strategy). However, another aspect that was considered was that the owner would reflect 'an average' NIPF owner. Therefore, forest owners with active forestry background or connections were not chosen for the interview. The data was gathered using a semi-structured interview guide. Eight NIPF owners between November 2014 and August 2015 were interviewed. The interviews lasted between 20 to 70 minutes. All the interviews 
General information about the interviewed forest owners and their forests

\begin{tabular}{|c|c|c|c|c|c|c|}
\hline $\begin{array}{c}\text { Number of } \\
\text { interview }\end{array}$ & Gender & $\begin{array}{c}\text { Age } \\
\text { (years) }\end{array}$ & $\begin{array}{c}\text { Number of } \\
\text { parcels }\end{array}$ & $\begin{array}{c}\text { Forest area } \\
\text { (ha) }\end{array}$ & $\begin{array}{c}\text { Owner since } \\
\text { (year) }\end{array}$ & $\begin{array}{c}\text { Distance from forest (from } \\
\text { residence, } \mathrm{km} \text { ) }\end{array}$ \\
\hline FO1 & Male & 22 & 1 & 8 & 2014 & 40 \\
\hline FO2 & Female & 28 & 8 & 20 & 2008 & 55 \\
\hline FO3 & Male & 32 & 1 & 18 & 2013 & 35 \\
\hline FO4 & Male & 62 & 2 & 3 & 2013 & 33 \\
\hline FO5 & Female & 46 & 1 & 14 & 2008 & 237 \\
\hline FO6 & Male & 39 & 1 & 18 & 2008 & 25 \\
\hline FO7 & Male & 55 & 4 & 5 & 1993 & 2 \\
\hline FO8 & Male & 50 & 3 & 6 & 1993 & 0.2 \\
\hline
\end{tabular}

were recorded with the interviewees' permission. The recordings were fully transcribed for the analysis. A general overview about the interviewees and their characteristics is provided in Table 2 .

A motive is a reason that makes (or might make) a person choose to act in a certain way and the reasons might reflect e.g. persons' needs or objectives. The latter are more general and long-term thus depending on the situation and institutional arrangement a particular behavioural choice might not reflect the person's initial objective. The objectives and motives were therefore analysed using two main themes. Firstly, all the transcriptions were analysed several times and all the parts where objectives were mentioned the text was indexed as 'OO' (ownership objectives). Secondly, the past or present forest use was identified and indexed with the abbreviation 'FO' (forest use). During this first step, the principles of open coding were applied. The second step of analysis included a segmentation of the identified parts of the text into categories of ownership objectives adopted from Põllumäe, Korjus, \& Paluots (2014b). This was done in order to simplify and systematize the data for further analysing. Within these segments, the different aspects of these broader categories of ownership motives were then explored. The interviewees were also asked to describe themselves as forest owners and talk about their forest. In addition, the ways of becoming a forest owner were explored. Specific issues like ownership duration, past and present forestry activities, future plans, objectives, actual forest work conduced, frequency of forest visits and duration of stays were asked. Eventually, the interviewees were asked what forest ownership means to them.

\section{Results and Discussion}

Ownership objectives

Financial considerations or income motives were found in all eight interviews. One very distinct form of this motive was the indication that the forest provides some economic security either for the current or future generations. In addition, it is as a pension fund or a safe capital investment in case of emergent needs. This income motive is further looking and considers future prospects.

"[the forest] gives confidence, it is a guarantee in case something happens. If, for example, there is a shortage of money or if there are some health issues." FO1.

"Forest ownership means that you are like a king. It's like independence - if you have land then you are "the man", you are independent. It is like a great trump ace in your pocket, just in case, whatever happens." FO2

None of the eight forest owners indicated that there would be some direct (or sustained) economic expectations from forest management. Nevertheless, there were cases of forest harvesting and income generation. In many of such situations, the income was at least partially re-invested in forest management. In two specific cases, the forestry income was or is important to develop the property or own business further. Clear cuts have mostly been done by professionals and organized by forest owners' associations (FO2, FO3, FO5). In case of smallerscale work (sanitary cuttings, thinnings) either local workforce (FO1, FO4) was used or the forest owners themselves (FO7, FO8) had done the work. In most cases (FO2, FO3, FO5, FO7, FO8) the forest owners had valid forest management plans and the plan seemed to be an important part of their forestry behaviour.

"The numbers [income from harvesting] were so small, but I had to do it, because I [when buying the property] booked my money into this, but I still need funds to make and maintain some roads. /..../ The market conditions were 
not good, among others. But the plan was in place and it [the harvest] was done. I am not the "let's-wait and see" kind of person". FO 3

"The main business is still the livestock. If I have to buy more agricultural land, then I would sell some forest." FO7

In addition, it seemed that owners with stronger emotional bonds to the land were more eager to invest back to the forest (e.g. reforest, afforest, young stand development etc.) or they saw their activities as not just forest management, but as 'fixing' the forest (e.g. FO1). Other income motivated plans or activities were mostly related to the particular forest. However, they differed fundamentally from the previous cases where the income was re-invested. In the latter case, the forest owners saw it as an investment to other land uses, whereas the other owners saw it as an investment to forestland development.

"The purpose of the harvesting was that this money could be used to take care of the rest of "underwood" [referring to the need to make thinnings]." FO5

"It makes sense to re-invest back to the forest. Most idiotic would be getting the money and spend it on just things. Most reasonable would be the [investing into] maintenance of young growth forests or standing forest." FO2

Consumption for own needs was quite an integral part of the investigated forest owners' objectives. In six cases out of eight such notions of objectives were identified. In all these cases, some need for firewood was mentioned. In most cases, the forest owners and their families themselves gathered the firewood. Moreover, if some additional help was used it was usually the local neighbouring persons. In addition to firewood, Christmas trees (FO2) and saw logs (FO2, FO7, FO8) were also mentioned. In such cases, the saw logs were also used for own purposes and in some cases (FO7) further processed to have boards.

"I could bring a Christmas tree from my own forest. And I could take firewood, because why should I pay for it when I've got my own forest. I don't have to have a permit to make firewood from my own forest, do I?" FO2

"[when asked how much time the owner spends in the forest] To fill up the shed with firewood and to makes sure the edges of the fields are clean from brushes." FO7

Different notions where the forest property was linked to be a 'home' were found in seven interviews out of eight. It was expressed directly either if there was a summer house nearby (FO1, FO3, and FO4) or the forest owner lived on the property (FO7). There were also future plans expressed (FO2, FO6) where forest owners indicated the wish to live on the property. In one case (FO5) the physical linkage with the property has weakened as the forest owner lives almost 240 kilometres away in the city; however, the emotional connection is still present.

“/.../ And since I do not have any connections anymore in South-Estonia and I still have to go to a salaried work. /..../ We indeed still have the foundation there in the property but no house. I could go with a tent, but...no." FO5

Non-wood products and services were of less significant to the owners. In four cases out of eight different non-wood motives were present. In one case, such motive was not even linked to the forest itself but the property in general (FO3) as the forest owner indicated the wish to have some small agricultural beds. In addition, the same owner mentioned a plan to have a hiking trail on the property. Most of the non-wood uses were identified with owners who lived close to the property or who frequently visited the place. Most commonly, not only mushroom and berry picking was mentioned (FO6, FO7), but also hunting (FO7).

"[When asked about how often the owner visits the forest] Five times a week. If I include hunting, then even more I guess. If I'm hunting, then in autumn 4-5 times a week plus weekends. /..../I'm not an active picker, but when I'm there I definitely pick the chanterelle [Cantharellus cibarius], some 3-4 times at least. For selfuse. In autumn, some lingonberries and cranberries. But not on a large scale, it is still a hobby." FO7

In addition, nature conservation was not identified directly as a motive or objective. However, in at least two cases some notions were identified where forest owners reflected the importance of their forest on a more landscape level. For example, FO3 wanting to establish a home on the property, indicated that the "forest is like a fur coat around the house". Also, it "keeps privacy and creates environment and cosiness". Such deeper motives for ownership were mostly present in cases where the forest owners also related to the 'home' motive presented earlier.

"In fact, the forest around the house is more like a part of the surrounding greenery. I do not think of it as a source of income, but as a part of the landscape. /.../" (FO4) 
Many of the interviews reflected directly to previous or past ownership of the forest. Only in a few particular cases the owner had either bought the property nevertheless he characterized himself as a city person (FO3) or he and his family directly lived on the property (FO7, FO8). However, in the FO3 case, the objective of the ownership was also establishing home in the long term with the forest being a part of the landscape on the one hand, and on the other hand providing some financial resources to develop the property as a whole.

" /..../ There is a strong emotional bond. I could not imagine selling it off. I .... It is not like an apartment in Tallinn what you can just buy and sell. It is different. /...." (FO3)

In most of the interviewees the forest had been inherited and quite an important part of the ownership seems to be linked to the roots of the ownership (FO4, FO5), the influences of past generations (FO1, FO2) or to a sense of responsibility (FO1, FO2, FO5). Some forest owners knew very well the historical background of the forest property even dating back to early $20^{\text {th }}$ century (FO4). Others had more close connections with the previous owning generation (FO1, FO2).

"/.../ Their [parents] intention was that land has value and it will ensure welfare. /..../" FO2

For example, FO5 lives approximately 240 kilometres away from the forest, but still stresses the importance of regeneration of the harvested stands and still manages in her own way the forestland despite of the weak physical connection.

"It's an issue of identity, that there would be some continuity. I..../ We won't get anything anymore, but our children perhaps if there is something. When times are bad, you can take something. Or like a land, like a piece of Estonia, I have the land." FO5

However, in many cases where such sense of responsibility can be identified it can also be seen that it is individual and it is not somehow imposed to future generations (FO2, FO4, FO8). There are no expectations from the future generations to hold on to the property. In this case, also exceptions existed (MO1, MO2).

Põllumäe, Korjus, \& Paluots (2014b) identified empirically five general motives for forest ownership and management in Estonia - a conservation motive, non-wood motive, income motive, 'home' motive, and self-consumption motive. Following the same categories, it was found in the interviews, that indeed, quite similar categories are present. The biggest distinction with Põllumäe, Korjus, \& Paluots (2014b) was that there were no identifications of special forest conservation objectives in the interviews. Instead, some landscape-related aspects were identified. The level of specificity of other motives was much more abundant. The qualitative approach enabled to distinguish different aspects of single objectives. We found strong linkages between the family ties and personal identity. Grubbström (2011) who concludes that these emotional linkages are often historical has drawn similar findings. She stresses three main reasons - the loss of land during the Soviet annexation in 1940; the representation of the land as family roots and the presence of memories of the land and area in general. Very similar conclusion could be also drawn from this analysis, as there were forest owners with very detailed knowledge about the past of the property (e.g. FO4); there were important family roots (e.g. FO1, FO2, FO5) or some family- or place-related memories (FO1, FO4). Jörgensen \& Stjernström (2008) show that stronger emotional linkages are present in case of inherited forest, and that the emotional values often outweigh the economic ones. However, our study also suggests the opposite with the FO3 have bought the forest and presents strong emotional values with no intentions to sell. But in case of FO8 who inherited the property, the willingness to sell it off if it would be needed, is clearly present. Bengston, Asah, \& Butler (2010) when analysing an open-ended question for ownership reasons, also found a variety of family related aspects like legacy and heritage. Also Lind-Riehl et al. (2015) have found very strong links between NIPF decision-making and family influences. Such similar diversity and deeper meanings in the present study were also identified under the 'income' theme. The forestland is thus seen as a solid investment or back-up in case of sudden emergencies. In addition, it is a source for further property development. Lönnstedt (1997) found that most NIPF owners he studied also indicated the wish to preserve and develop the forest area further. Bengston, Asah, \& Butler (2010) presented also similar results. So actually, the "income" motivation encompasses a huge variety of different considerations and preferences, which influence the actual behaviour of the owner.

The core values and objectives establish the foundation for PFO individual decision-making, but also the situational and institutional aspects influence the final decision (Karppinen, 1998) or actual behaviour. Such a relationship was also present in almost all of the studied interviewees. Much of the income-related motivations were influenced by other external factors such as market conditions (FO2), 
stand condition (e.g. beetle, wind damage in FO4) or planned or unexpected financial needs (FO3, FO8). Bliss and Martin (1989) concluded also that different external influence merely adjusts the timing and scale of forest management activities. This approach is different from what Stanislovaitis et al. (2015) indicated. Stanislovaitis et al. (2015) stated that the forest characteristics (size, condition) influence the objectives. However, relying on Bliss and Martin (1989) and the current study, we would oppose Stanislovaitis et al. (2015), and propose that the forest property characteristics only influence the realization (both in terms of quality and quantity) of the aim. In principle, the value-based general objective itself (e.g. income) is universal. It is therefore that different policy tools (i.e. an institutional aspect) influence the behaviour of NIPF owners, but they still do it under certain situational conditions. Each external situational aspect (e.g. the NIPF owners' forest is damaged by wind) also has different influences to the forest owners since their physical or emotional linkages with the property differ. In addition, there are varieties of situational aspects that are present and interact at the same time as well. Forest policy can deal with this in many ways - have more costly policies and tools, which might provide better results from an individual forest owners perspective or have a more generalized approach, which is cheaper, provides more generalized results and might not accost to the individual forest owner.

As the approach of this study has been qualitative and the objectives and motives of NIPF owners have been under investigation, there are no generalizations or statistical analysis in this paper. It is therefore impossible to weigh or measure otherwise the proportions of one or another motive. Instead, we focused on having a rich data, which could enable us to go deeper than just one generalized objective or motive. From a methodological point of view, it is important that both quantitative segmentation and qualitative approaches have their place in forest ownership research. Moreover, the results of this study indicate that using both approaches in a mixedmethod way could be even more appropriate and enlightening, as from a broad classification (based on generalized values) the researcher would be able to specify each of the group deeper (i.e. looking at the institutional and situational aspects) offering a continuous look at the development of objectives and thus decision-making. Fischer et al. (2013) who used such mixed-methods approach have also made such a conclusion. Also, many aspects of forest ownership seem to link with the place itself and how the forest property is understood and perceived. Therefore, we suggest that the different aspects of place attachment could be one possible future option in small-scale forestry research. This would provide us with a deeper understanding how the place itself influences the person-place relationship and whether and how different objectives of forest ownership are influenced by the forest property.

\section{Conclusions}

Based on the previous sections of the paper, we draw the following conclusions and general remarks for future research directions:

1. Among our respondents, we have identified even broader ownership objectives than just conservation, non-wood, income, 'home' and selfconsumption motives and explained how such objectives actually come to life and influence the decision-making of the forest owners and thus the landscape itself.

2. The presented diversity of forest ownership illustrates quite well that in order to preserve a multiple-use forestry and diverse landscapes it would be reasonable to encourage diverse NIPF ownership. On a general level such as a country, diverse ownership could cover all the environmental, social and economic components of sustainability.

3. Qualitative methods in small-scale forestry research provide new insights to forest ownership and its meanings. This approach enabled us to open up rich and colourful meanings of some generalized ownership classifications that are often used to characterize and generalize forest ownership and owners.

\section{Acknowledgements}

This study was supported by the institutional research funding (IUT21-4) of the Estonian Ministry of Education and Research. We would like to thank Monika Suškevičs and Marius Kavaliauskas for their valuable comments to the earlier version of the manuscript.

\section{References}

1. Bengston, D.N., Asah, S.T., \& Butler, B.J. (2011). The Diverse Values and Motivations of Family Forest Owners in the United States: An Analysis of an Open-ended Question in the National Woodland Owner Survey. Small-Scale Forestry 10(3), 339 - 355.

2. Bliss, J.C., \& Martin, A.J. (1989). Identifying NIPF management motivations with qualitative methods. Forest Science 35 (2), $601-622$. 
3. Fischer, A.P., Kline, J.D., Charnley, S., \& Olsen, C. (2013). Erratum to Identifying policy target groups with qualitative and quantitative methods: The case of wildfire risk on non-industrial private forest lands [Forest Policy and Economics 25 (2012) 62-71]. Forest Policy and Economics 28, 69 - 78.

4. Grubbström, A. (2011) Emotional bonds as obstacles to land sale - Attitudes to land among local and absentee landowners in Northwest Estonia. Landscape and Urban Planning 99, 31 - 39.

5. Jörgensen, H., \& Stjernström, O. (2008). Emotional links to forest ownership. Restitution of land and use of a productive resource in Põlva County, Estonia. Fennia 186, 95 - 111.

6. Karppinen, H. (1998) Values and Objectives of Non-industrial Private Forest Owners in Finland. Silva Fennica 32(1), $43-59$.

7. Keskkonnaagentuur (2016). Aastaraamat Mets 2014 (Yearbook Forest 2014). Tallinn: Keskkonnaagentuur. (in Estonian).

8. Leemet, A. \& Karoles, K. (1995) Estonian forests and forestry. Baltic Forestry 1(1), 30 - 34.

9. Lind-Riehl, J., Jeltema, S., Morrison, M., Shirkey, G., Mayer, A.L., Rouleau, M., \& Winkler, R. (2015). Family legacies and community networks shape private forest management in the western Upper Peninsula of Michigan (USA). Land Use Policy 45, 95 - 102.

10. Lönnstedt, L. (1997) Non-industrial private forest owners' decision process: A qualitative study about goals, time perspective, opportunities and alternatives. Scandinavian Journal of Forest Research, 12(3), $302-310$.

11. Meikar, T., \& Etverk, I. (2000). Metsaomand Eestis (Forest ownership in Estonia). Metsanduslikud Uurimused /Forestry Studies XXXII, 8 - 18 (in Estonian).

12. Ministry of Environment. (2015) Eesti erametsaomandi struktuur ja kasutamine 2015. aastal (The structure and use of Estonian private forests in 2015). Tartu: Keskkonnaministeerium (in Estonian).

13. Ministry of Environment. (2011) Eesti erametsaomandi struktuur ja kasutamine 2010. aastal (The structure and use of Estonian private forests in 2010). Tartu: Keskkonnaministeerium (in Estonian).

14. Patton, M.Q. (2014). Qualitative research and evaluation methods (4th ed.). Los Angeles, CA: Sage.

15. Pregernig, M. (2010). Values of Forestry Professionals and their Implications for the Applicability of Policy Instruments. Scandinavian Journal of Forest Research 16(3), 278 - 288.

16. Põllumäe, P., Lilleleht, A., \& Korjus, H. (2016). Institutional barriers in forest owners' cooperation: The case of Estonia. Forest Policy and Economics 65, $9-16$.

17. Põllumäe, P. (2015). Ülevaade metsaomanike klassifitseerimisest Ida-Euroopa riikides: metodoloogilisi ning metsapoliitilisi aspekte (A review on forest owner classifications in Eastern-Europe - methodological and policy-related aspects). Agraarteadus Journal of Agricultural Science 26(2), 76 - 83 (in Estonian).

18. Põllumäe, P., Korjus, H., Kaimre, P., \& Vahter, T. (2014a). Motives and Incentives for Joining Forest Owner Associations in Estonia. Small-scale Forestry 13(1), 19 - 33.

19. Põllumäe, P., Korjus, H., \& Paluots, T. (2014b). Management motives of Estonian private forest owners. Forest Policy and Economics 42, 8 - 14.

20. Sepp, T. (2008). Erametsaomanike klassifitseerimise võimalused ja nende rakendamine Eestis (Private forest owners classification options and their implementation in Estonia). MSc thesis, Estonian University of Life Sciences, Tartu, Estonia (in Estonian).

21. Stanislovaitis, A., Brukas, V., Kavaliauskas, M., \& Mozgeris, G. (2015). Forest owner is more than her goal: a qualitative typology of Lithuanian owners. Scandinavian Journal of Forest Research 30(5), 478 491.

22. Toivonen, R., Järvinen, E., Lindroos, K., Rämö, A.-K., \& Ripatti, P. (2005). The challenge of information service development for private forest owners: the Estonia and Finland cases. Small-Scale Forest Economics, Management and Policy 4(4), $451-470$.

23. Weber, N. (2012). Reflections on theories in forest policy: Testing, combining or building? Forest Policy and Economics 16, $102-108$.

24. Zhang, Y., Zhang, D., \& Schelhas, J. (2005). Small-scale Non-industrial Private Forest Ownership in the United States: Rationale and Implications for Forest Management. Silva Fennica 39(3), 443 - 454. 